\title{
Spindle Cell (Sarcomatoid) Squamous Cell Skin Carcinoma
}

National Cancer Institute

\section{Source}

National Cancer Institute. Spindle Cell (Sarcomatoid) Squamous Cell Skin Carcinoma. NCI

Thesaurus. Code C4666.

A squamous cell carcinoma of the skin with a prominent spindle cell component. 